\title{
Antidepresant effects of Cinnamon (Cinnamomum burmannii) extract in depressed induced rats using 3-minutes Tail Suspension method
}

\author{
Nita Parisa ${ }^{1}$, Mayasari $^{2 *}$, Nia Savitri Tamzil ${ }^{1}$, Bintang Arroyantri ${ }^{3}$, Ziske Maritska ${ }^{4}$ \\ ${ }^{1}$ Department of Pharmacology, Faculty of Medicine, Universitas Sriwijaya \\ ${ }^{2}$ Undergraduate, Faculty of Medicine, Universitas Sriwijaya \\ ${ }^{3}$ Department of Psychiary, Faculty of Medicine, Universitas Sriwijaya \\ ${ }^{4}$ Department of Biology Medicine, Faculty of Medicine, Universitas Sriwijaya \\ \# Corresponding Author: Mayasari.may4sari@gmail.com \\ Received : June $19^{\text {th }} 2019$ \\ Accepted :August $10^{\text {th }} 2019$
}

\section{Background}

\section{ABSTRACT}

The increasing prevalence of depression gives rise to challenges in not only elucidating its diverse causes, but also in finding an effective treatment. One of the factors linked to depression is the imbalance of serotonin, norepinephrine, and dopamine neurotransmitters. Cinnamon (Cinnamomum burmannii) as one of the world's wellknown cooking ingredients is believed to be able to regulate the neurotransmitters imbalance with the help of terpenoids and flavonoid polyphenols as one of its content.

\section{Objective}

This study aims to determine the effectiveness of cinnamon extract as an antidepressant in depressed induced animal model.

\section{Methods}

An experimental in vivo with pre-post control group design was conducted in twenty five Wistar strain white rats that were divided into 5 treatment groups that received fluoxetine as positive control, aquades, and different dose of cinnamon extracts $(50 \mathrm{mg} / \mathrm{kgBW}, 100 \mathrm{mg} / \mathrm{kgBW}$, and $200 \mathrm{mg} / \mathrm{kgBW})$. Depression induction method used was 3-minute Tail Suspension Test, done for 14 days. The antidepressant effectiveness test was carried out by calculating the immobility time duration with Forced Swimming Test method and was further analyzed using one-way ANOVA test.

Results

One-way ANOVA test results showed that there were differences in the mean duration of immobility time between treatment groups after being given cinnamon extract ( $p$ value $=0,000$ ). Groups that were given $100 \mathrm{mg} / \mathrm{kgBW}$ cinnamon extract and $200 \mathrm{mg} / \mathrm{kgBW}$ showed a p value $>0.05$ when compared with positive control group receiving Fluoxetine although displayed a similar reduced immobility time.

\section{Conclusion}

Cinnamon (Cinnamomum burmannii) extract showed a promising potential as an effective antidepressant tested in animal model.

Keywords: cinnamon, extract, depression, immobility time, rat 


\section{Introduction}

Depression is a condition that contributes greatly to the occurrence of suicides every year ${ }^{1}$. The prevalence of depression continues to increase with a risk of two to three times more frequent in women than men. Depression itself is characterized by emotional disorders in the form of depressive affect, anxiety, decreased concentration, loss of interest, and loss of energy in doing daily activities. It is known to be influenced by several factors including genetics, environmental, one's personality, as well as abnormalities in the number and function of neurotransmitters in body.

Depression is often not only a one-time episode but it can occur repeatedly, leading to impairment in one's activities. A person who experienced depression should be treated with proper management, one of them is pharmacological treatment. Current drug of choice for depression is the Selective Serotonin-Reuptake Inhibitor (SSRI) group which has lower side effects compared to previous drug of choice which was MAOI antidepressants and tricyclics ${ }^{2}$. Yet the use of SSRI shows various side effects such as sexual dysfunction in women in the form of decreased libido, and anorgasmia arousal and erectile dysfunction in men ${ }^{21 .}$

Cinnamon (Cinnamomum burmannii) as one of the commonly found cooking ingredients worldwide including in Indonesia is believed to provide health benefits. Cinnamon (Cinnamomum burmannii) contains various chemical compounds like flavonoid and terpenoid polyphenols that work as an antidepressant through a mechanism that is in line with the theory of BDNF's influence on depression, neuroinflammation, and the presence of free radicals in the pathogenesis of depression hypothesis ${ }^{3,4,5}$ As a traditional herb with long history of usage in cooking, it is also believed that cinnamon posseses a very small risk of toxicity. Thus it is believed to be an alternative treatment for depression with a minimum side effects.

\section{Methods}

This was an experimental in vivo study with pre-post control group design. As many as twenty five white male wistar rats were divided into 5 groups. The first group was administered with fluoxetine as a positive control, the second group was administered with aquadest as a negative control, third, fourth, and fifth group were administered with various dose of Cinnamon extracts, namely 50 $\mathrm{mg} / \mathrm{KgBW}, 100 \mathrm{mg} / \mathrm{KgBW}$ and 200mg/KgBW. 


\section{ISSN 25980580}

\section{Phytochemical Test}

In this study, a phytochemical test was conducted to identify active compounds in the cinnamon extract. The examinations carried out were tests of flavonoids, phenols, alkaloids, quinones, steroids, saponins, and tannins.

\section{Cinnamon Extract}

Two hundred and fifty grams of powder Simplicia cinnamon was macerated with $96 \%$ ethanol. Extracts was then obtained through evaporation using vacuum rotary evaporator, before it then dried and crushed to homogeneous.

\section{Administration of antidepressant drugs}

The antidepressant drug as positive control being used in this study was a $20 \mathrm{mg}$ fluoxetine capsules. Since the usual dosage in adult humans is around $20 \mathrm{mg}$, then the dose of Fluoxetine for mice is being converted with following equation: $70 / 50 \times 20 \mathrm{mg} \times 0.018=0.504 \mathrm{mg} / 200 \mathrm{gBW}=2.52 \mathrm{mg} /$ $\mathrm{KgBW}(0.018$ is the dose conversion factor from human to rat).

\section{Antidepressant Test for Cinnamon Extracts}

Twenty five rats were divided into 5 groups where it underwent the depression induction for two weeks. All the animals were hanging in a pole as high as $\pm 50 \mathrm{~cm}$ for 3 minutes before they were being weighted and observed for depression behavior. After being treated with cinnamon extracts for two weeks, the test animals then underwent a post-test which is Forced Swimming Test (FST) to assess the effectiveness of each cinnamon extracts ${ }^{6.7}$. The FST was carried out in an open tube $( \pm 50$ height $\mathrm{cm}, 20 \mathrm{~cm}$ in diameter) containing water with a height of $30 \mathrm{~cm}$. The last 8 minutes, 2 minutes of the first as acclimatization and 6 minutes as the calculation of immobility time of test animals.

\section{Results}

Results manufacture simple worth as much as 250 grams of the extract obtained as much as 26 grams with results Rdt $10 \%$. The phytochemical test was carried out to cinnamon extract with the following results:

\section{Table 1. Phytochemical Test}

\begin{tabular}{llc}
\hline Examination & Results & Identification \\
\hline Phenol & colour black strong & + \\
Flavonoids & colour orange & + \\
Alkaloids & formed colour red & + \\
\hline
\end{tabular}




\begin{tabular}{llc}
\hline Steroids & Blue & + \\
& $1.5 \mathrm{~cm}$ foam not lost given HCL & \\
Saponin & $2 \mathrm{~N}$ & + \\
Quinon & Red & + \\
Tanin & Black & + \\
\hline
\end{tabular}

There were behavioural changes observed after the induction. Majority of the rats showed a decreased appetite hence the decreasing body weight as it can be seen on table 1. The rats also showed passive behaviour compared to before induction.

Table 1. Body Weight Before and After Induction

\begin{tabular}{llll}
\hline Group & $\mathrm{N}$ & $\begin{array}{l}\text { Before Weight Loss Induction } \\
\text { Average } \pm \mathrm{SD}\end{array}$ & $\begin{array}{l}\text { Body Weight After Induction } \\
\text { Average } \pm \mathrm{SD}\end{array}$ \\
\hline Fluoxetine & 5 & $218.6 \pm 7.7$ & $212.8 \pm 12.3$ \\
Aquades & 5 & $215.6 \pm 8.1$ & $211.6 \pm 11.1$ \\
Cinnamon Extract 50 & 5 & $203.8 \pm 4.7$ & $181 \pm 17.8$ \\
Cinnamon Extract 100 & 5 & $197.4 \pm 3.5$ & $198.8 \pm 8.4$ \\
Cinnamon Extract 200 & 5 & $210.2 \pm 13.6$ & $197.4 \pm 12.2$ \\
\hline
\end{tabular}

Soon after each group was being given cinnamon extract for two weeks, a post-test was carried out. Immobility time data is presented in the following table 2.

Table 2. Differences between immobility time pre-test and post-test

\begin{tabular}{lccc}
\hline & Immobility Time Pre & Immobility Time Post & p-value \\
Treatment Group & $\pm \mathrm{SD}$ & $\pm \mathrm{SD}$ & \\
\hline Fluoxetine & $142.8 \pm 8.07$ & $62.8 \pm 8.4$ & 0,000 \\
Aquades & $133.4 \pm 10.9$ & $145.2 \pm 9.7$ & 0.226 \\
Cinnamon Extract 50 & $140.4 \pm 6.02$ & $134.8 \pm 7.79$ & 0.181 \\
Cinnamon Extract 100 & $135.4 \pm 6,2$ & $74.8 \pm 7.75$ & 0,000 \\
Cinnamon Extract 200 & $142.4 \pm 14.7$ & $61.2 \pm 13.1$ & 0,000 \\
\hline
\end{tabular}

Paired Sample T Test , $p<0.05$ 
Differences in immobility time pre-test and post-test in each treatment group was analyzed using the Paired Sample T Test. As it can be seen in table 2, there were differences in the mean Immobility time pre-test and post test in three groups: fluoxetine group ( $p$ value $=0,000)$, cinnamon extract 100 $\mathrm{mg} / \mathrm{kgBW}$ ( $p$ value $=0,000)$, cinnamon extract $200 \mathrm{mg} / \mathrm{kgBW}(p$ value $=0,000)$. The other two groups which are aquades $(p$ value $=0.226)$, and cinnamon extract $50 \mathrm{mg} / \mathrm{kgBW}(p$ value $=0.181)$, showed no differences in mean immobility time pre-test and post-test.

Table 3. Differences in Average Immobility Time Post-Test

\begin{tabular}{lcll}
\hline Treatment Group & N & Average \pm SD & P value \\
\hline Fluoxetine & 5 & $63.8 \pm 8.4$ & \\
Aquades & 5 & $147.2 \pm 9.7$ & \\
Cinnamon Extract 50 & 5 & $137.8 \pm 7.7$ & 0,000 \\
Cinnamon Extract 100 & 5 & $78.8 \pm 7.7$ & \\
Cinnamon Extract 200 & 5 & $66.2 \pm 13.1$ & \\
\hline
\end{tabular}

one way anova , $p<0.05$

Based on the one-way ANOVA test, difference meaningful immobility time deliver group treatment, then post hoc tests were compared to each treatment group. fluoxetine group compared with the Aquades group and the group of cinnamon extract dose $50 \mathrm{mg} / \mathrm{kgBW}$ obtained $p$-value $0,000(\mathrm{p}$ $<0.05)$ the meaning different significant whereas the fluoxetine group is compared with cinnamon extract dose of 100mg / $\mathrm{kgBW}(p$-value $=0.225)$ and $200 \mathrm{mg} / \mathrm{kgBW}(p$-value $=1,000)$ which means there is no significant difference on group, so be concluded that the dose of cinnamon extract having an effective similar to those observed with fluoxetine in reducing immobility time on rat there is on cinnamon extract of $100 \mathrm{mg} / \mathrm{kgBW}$ and $200 \mathrm{mg} / \mathrm{kgBW}$.

\section{Discussions}

Before the test animals were given an induction of depression, all test animals were weighted. After the two weeks induction, the test animals were weighted again. It can be inferred from table 1 that there were changes in weight before and after the induction. These changes might be due to changes in appetite becaused of the occurence of depression in animal test. Dietary symptoms including changes in appetite are one of the most commonly identified symptoms in depression. Some experience decrease of appetite (35\%), while some experience increase of appetite (48\%). These two 
conditions are caused by different mechanism in quite a same pathway. Major depression with an increased appetite is caused by increased activity of blood-oxygen-level-dependent (BOLD) in the brain involving the reward system (anterior insula, orbitofrontal cortex, ventral striatum, the ventral pallidum, and putamen), while major depression with decreased appetite decreases blood-oxygenlevel-dependent (BOLD) activity in the mid-insula part ${ }^{8}$.

The cinnamon extracts contain various substances with cinnamaldehyde as the major component. Cinnamaldehyde metabolism in the body produces sodium benzoate $(\mathrm{NaB})$ metabollite where $\mathrm{NaB}$ is thought to be able to increase BDNF neurotrophin expression in vivo in rat ${ }^{3}$. In addition to cinnamaldehyde, cinnamon extracts also contain other active substances namely proanthocyanidin which includes condensed tannin compounds ${ }^{10}$. Proanthocyanidin is proved to be protective against depression and anxiety, where it has antidepressant activity by increasing BDNF expression in the hippocampus and frontal cortex of chronically stressed mice ${ }^{11}$. The application of chronic stress can provide a variety of effects on the neuron system, one of which is a decrease in the synthesis of BDNF mRNA in the hippocampus which causes a decrease in serotonin as one of the most important factors in depression. In another study, it was found that administration of antidepressants can increase BDNF and the administration of BDNF infusion has an antidepressant effect ${ }^{12}$.

In previous study it was stated that Cinnamon extracts increase dopamine at doses of $50 \mathrm{mg} /$ $\mathrm{kgBW}, 100 \mathrm{mg} / \mathrm{kgBW}$ and $200 \mathrm{mg} / \mathrm{kgBW}^{13}$. In depression, dopamine dysfunction can cause dysregulation in the reward, arousal or spirit system, making depressed people became hedonic deficits ${ }^{14}$. Aqueous extract of cinnamon for 6 days can reduce lipopolysaccharide which induces tumour necrosis factor- $\alpha$ ( TNF- $\alpha$ ) in serum. TNF- $\alpha$ is stated to be able to induce depressive behaviour, which in line with the discovery of elevated serum levels of $I L-1 \beta, I L-6, I L-8, I L-12$ and $T N F-\alpha$ together with a decrease in anti-inflammatory $I L-10$ in depressed people ${ }^{15}$. A meta-analysis study proves that there is a decrease in $\mathrm{IL}-1 \beta$ for administration antidepressant SSRI ${ }^{19}$. The presence of inflammation is thought to cause microglia activation which is associated with hippocampal connectivity disorders that affects on depression. Other hypothesis mechanism in depression like cytokine hypothesis, is the activation of the Hypothalamic-Pituitary-Adrenal (HPA) axis. Its activation leads to the increment of cortisol, responding to inflammation by inhibiting Nuclear Factor Kappa B (NF-kB). However, excessive cytokines due to persistent inflammation can activate P38 Mitogen-Activated Protein Kinase (MAPK). This will further cause disruption of glucocorticoid receptor function which has an impact 
on failure of inhibition in NF-kB, leading to failure in inhibiting of the production of excessive cytokines ${ }^{16}$. The next hypothesis is that cytokines will activate serotonin transporters, which is an extracellular transporters that work to bring back serotonin (5-HT) to pre synapse due to activation of P38 MAPK ${ }^{17}$. The final hypothesis of depression is indoleamine-stimulating 2,3-dioxygenase (IDO) cytokines. It is an enzyme that convert the amino acid tryptophan as a 5-HT precursor to a kynurenine metabolite so there will be an imbalance in serotonin availability. This supports the results of research that proves the difference in 5-HT ratio to Kynurenine metabolites are found to be higher in depressed people ${ }^{18}$.

As previously stated, other than containing cinnamaldehyde, cinnamon is also known to contain others substances, like linalool and eugenol for intstance. These two substances are known to reduce lipid oxidation ${ }^{19}$. This function matters because lipid peroxidase will increase in conditions of psychological stress such as depression. The presence of lipid peroxidase activity causes free radical formation in major depressed patients and Generalized Anxiety Disorder (GAD) with the discovery of malondialdehyde (MDA). Another pathogenesis of depression is the presence of an oxidant and antioxidant imbalances due to an increase in glucocorticoid secretion which causes an increase in reactive oxygen production (ROS). The presence of MDA as an indicator of oxidative stress can cause a decrease in serotonin and inhibit serotonin from binding to the receptor ${ }^{17,18}$.

\section{Conclusion}

Certain dose of cinnamon extracts work effectively as an antidepressant in Wistar strain white rats that were induced with depression through two weeks of 3-minutes Tail Suspension method. Further investigation on its antidepressant potential in humans is needed.

\section{References}

1. WHO. 2017. Depression and other common disorders: global health estimates. World Health Organization, Geneva.

2. Lukluiyyati, N.R. Pola Pengobatan Pasien Depresi di Rumah Sakit Jiwa Dr. RM. Soejarwadi Provinsi Jawa Tengah Tahun 2009. Skripsi. Fakultas Farmasi Universitas Muhammadiyah Surakarta, Surakarta, 2010.

3. Jana A., K.K. Modi1, A. Roy, J. A. Anderson, R. B. van Breemen, K. Pahan. . 2013). Up-regulation of neurotrophic factors by cinnamon and its metabolite sodium benzoate: Therapeutic implications for neurodegenerative disorders. J Neuroimmune Pharmacol.; 8(3) pp: 739-755. 


\section{ISSN 25980580}

4. Hong, J., Yang G., Kim Y. Eom S. Lew J. Kang. H. (2012) 'Anti-inflammatory activity of cinnamon water extract in vivo and in vitro LPS-induced models', BMC Complementary and Alternative Medicine. BMC Complementary and Alternative Medicine

5. Lee, B. and Kim, Y. (2010) 'The Roles of BDNF in the Pathophysiology of Major Depression and in Antidepressant Treatment', Korean Neuropsychiatric Association.

6. Yan, H., X. CAO, M. Das, X. ZHU, T. GAO. (2010) 'Behavioral animal models of depression.

7. Puspitasari, L. (2017) 'dan kadar kortisol tikus jantan galur wistar yang depresi',

8. Baxter, L. C. 2016. Appetite Changes in Depression. Am J Psychiatry.

9. Mateos-Martín, M., - F. Elisabet, Q. Carmen, P. Jara, T. Josep. (2011) New identification of proanthocyanidins in cinnamon (Cinnamomum zeylanicum L.) using MALDI-TOF/TOF mass spectrometry Analytical and bioanalytical chemistry

10. Tu, W. Z., F. Wu, Q. Z. Yan, J. C. Pan (2014). protective effect of proanthocyanidins on depression and anxiety behaviour in chronically stressed rats. chinese journal of pharmacology and toxicology. 28 pp.345-350.

11. Martinowich, K. and Lu, B. (2008) 'Interaction between BDNF and Serotonin: Role in Mood Disorders', Neuropsychopharmacology Reviews.

12. Parisa, Nita; Kamaluddin, MT; Theodorus, Theodorus. (2018) The Efficacy of Cinnamomum burmannii Extract on the Protection of Neuronal Cell Death in Haloperidol Induced Male Wistar Rats. Bioscientia Medicina, [S.1.], v. 2, n. 4, p. 1-11, dec. 2018. ISSN 2598-0580.

13. Belujon, P. and Grace, A. A. (2017) 'Dopamine System Dysregulation in Major Depressive Disorders', International Journal of Neuropsychopharmacology.[online] 20, pp. 1036-1046.

14. Brites, D. and Fernandes, A. (2015) 'Neuroinflammation and Depression : Microglia Activation, Extracellular Microvesicles and microRNA Dysregulation', pp.1-20.

15. Więdłocha M, Marcinowicz P, Krupa R, Janoska-Jaździk M, Janus M, Dębowska W, Mosiołek A, Waszkiewicz N, Szulc A.(2018) Prog Neuropsychopharmacol Biol Psychiatry. Jan 3;80(Pt C):217226.

16. Felice, L. J. De (2016) 'A current view of serotonin transporters [ version 1 ; referees : 3 approved ] Referee Status ':, 5(0), pp. 1-7.

17. Sahin, C. S. Dursun, M. Cetin, F. Aricioglu (2016) 'Klinik Psikofarmakoloji Bülteni-Bulletin of Clinical The Neuroinflammation Perspective of Depression: Reuniting the Outstanding Mechanisms of the Pathophysiology The Neuroinflammation Perspective of Depression: Reuniting the Outstanding Mechanisms of the Pathophysiology', Klinik Psikofarmakoloji BülteniBulletin of Clinical Psychopharmacology

18. Rao, P. V. and Gan, S. H. (2014) 'Cinnamon: A Multifaceted Medicinal Plant'. Hindawi Publishing Corporation, Evidence-Based Complementary and Alternative Medicine

19. Bal, N., S.T. Acar, A Yazıcı, K. Yazıc1, L. Tamer (2012) 'Malondialdehyde and Vitamin and Generalized Anxiety', The Journal of Psychiatry and Neurological Sciences.

20. Juananda, D., D. C. R. Sari, D. Prakosa,N. Arfian, M. Romi (2015) 'Pengaruh Stres Kronik terhadap Otak: Kajian Biomolekuler Hormon Glukokortikoid dan Regulasi Brain-Derived Neurotrophic Factor (BDN) Pascastres di Cerebellum'. JIK.

21. Curr Drug Targets. 2018;19(12):1352-1358. doi: 10.2174/1389450117666161227142947 